\section{EL COMBATE CONTRA EL ÁNGEL}

Paz Errázuriz | Fotógrafa, Galería AFA

Estudios de Educación, Cambridge Institute of Education, 1966; estudios de Educación, Pontificia Universidad Católica de Chile, 1972 y estudios en Fotografía, International Center of Photography, Nueva York, 1993. Becaria Guggenheim (1986), Fundación Andes (1990) y Fulbright (en 1992). Su trabajo fotográfico en blanco y negro, expuesto en Chile y en el extranjero, ha abordado principalmente el género del documento social.

En 1995 recibió el premio Ansel Adams del instituto Chileno Norteamericano de Cultura y en 2005 obtuvo el Premio a la Trayectoria Artística del Círculo de Críticos de Arte de Chile y el premio Altazor. Fue cofundadora de la Asociación de fotógrafos Independientes (AFI). Actualmente vive y trabaja en Chile.

LA VIDA POR GLORIA

as fotografías de boxeadores que conforman la presente exposición de Paz Errázuriz pertenecen a la serie El combate contra el ángel, realizadas en un gimnasio de barrio de Santiago, entre los años 1987 y 1988 y exhibidas por primera vez en Galería La Plaza.

Ceñidos ambos contendientes, comparecen en medio del circo $^{1}$

Una larga investigación -tal como acontece en toda su prolífica obra- antecede las imágenes que el espectador tiene ante sí. Prolegómeno: el boxeo ha sido considerado como una práctica deportiva masculina, afectada legal y culturalmente por prejuicios de género.

Levantaron las robustas manos, acometiéronse y los fornidos brazos se entrelazaron.

Notará el espectador que estas fotografías están lejos de ser instantáneas de escaramuzas en el ring; la condición de "boxeadores", aquí, es fruto de una poética articulada por indumentarias y poses de los fotografiados, fuera de combate, ante la cámara. Rostros castigados. Manos en la cintura, delimitan inminentes golpes bajo el cinturón; protectores genitales y bucales; vendas y orejeras, ahuyentan la penuria; espantan la muerte. ¿Por qué Paz Errázuriz nombra esta serie El combate contra el ángel si estos gladiadores sólo posan frente a ella?

Crujían de un modo horrible las mandíbulas y el sudor brotaba de todos los miembros.

(Hacía un año que David Ellis Venegas había ingresado al boxeo profesional, antes de ser fotografiado por Paz Errázuriz: aquí comparece con premonitoria publicidad en su camiseta: sноск. Cuatro años después de ser fotografiado, el 20 de diciembre de 1991, perdió el título de Chile frente a Abdenago Jofré. Su precio: clínicamente muerto).

La fotografía desde siempre ha tenido enredos con la muerte. La fotografía, ángel de la historia, combate contra el tiempo. Boxeo y fotografía. Largo duelo.

Como una batalla de miradas. Por eso esto va mucho más allá de hacer una toma para capturar al otro; es un diálogo impresionante, una relación que se establece muy intensa que luego se esfuma pero queda en la fotografía. Paz.

Rita Ferrer
Bibliografía sugerida

FONTCUBERTA, Joan. Los colores de la carne. Centro José Guerrero, Granada, 2007. ELTIT, Diamela y Paz ERRÁZURIZ. El infarto del alma. Francisco Zegers editor, Santiago, 1994.

http://www.galeriaafa.com 


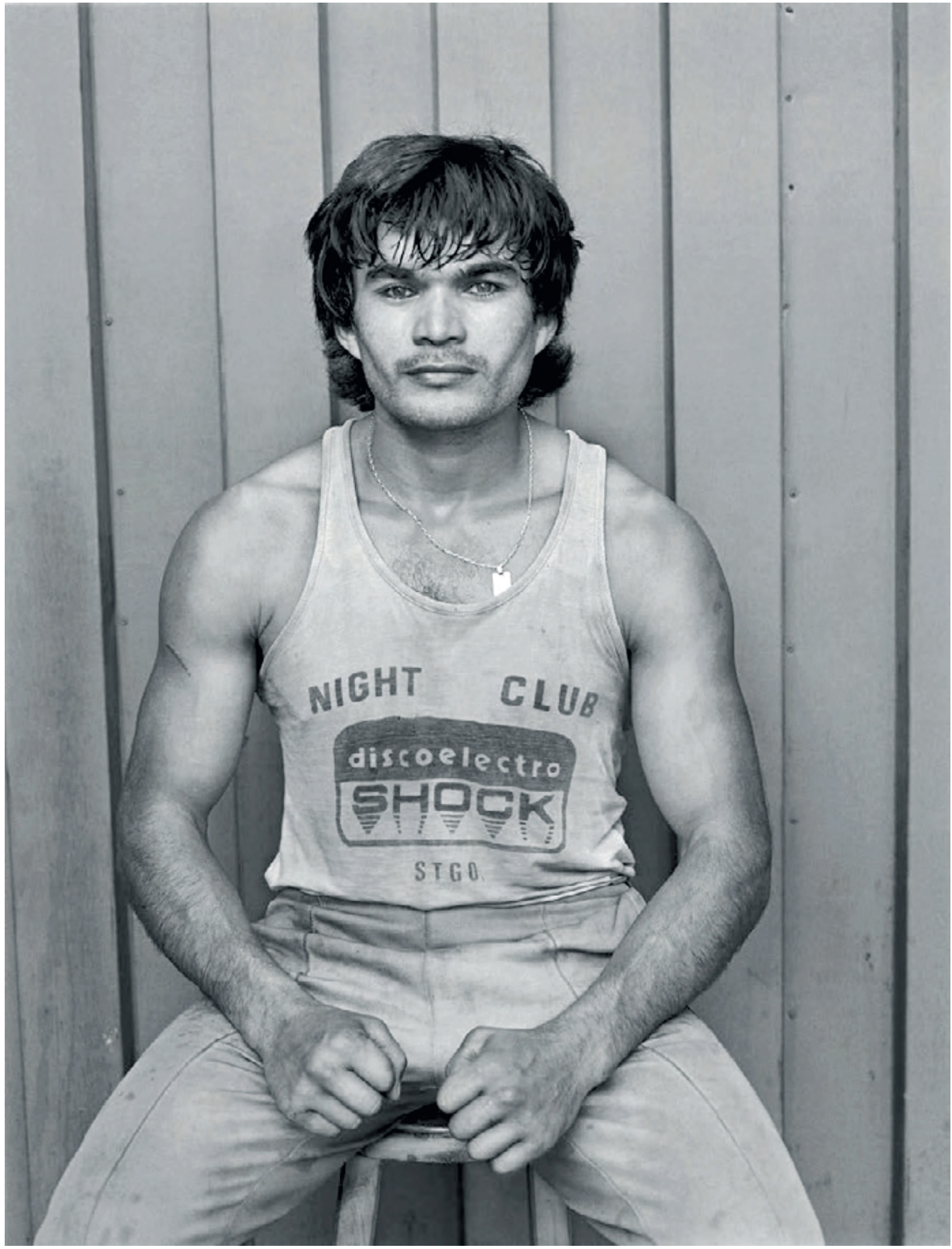




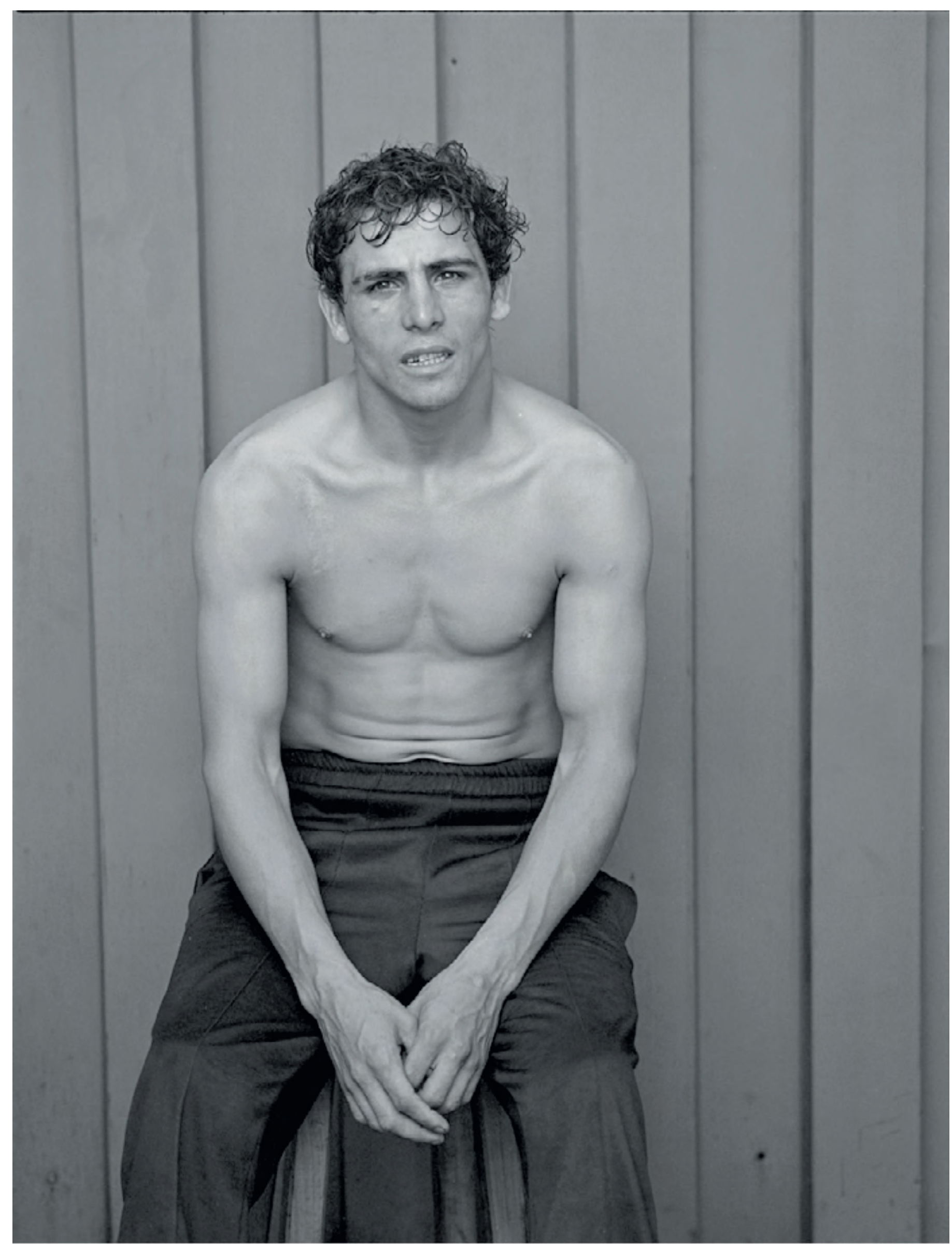




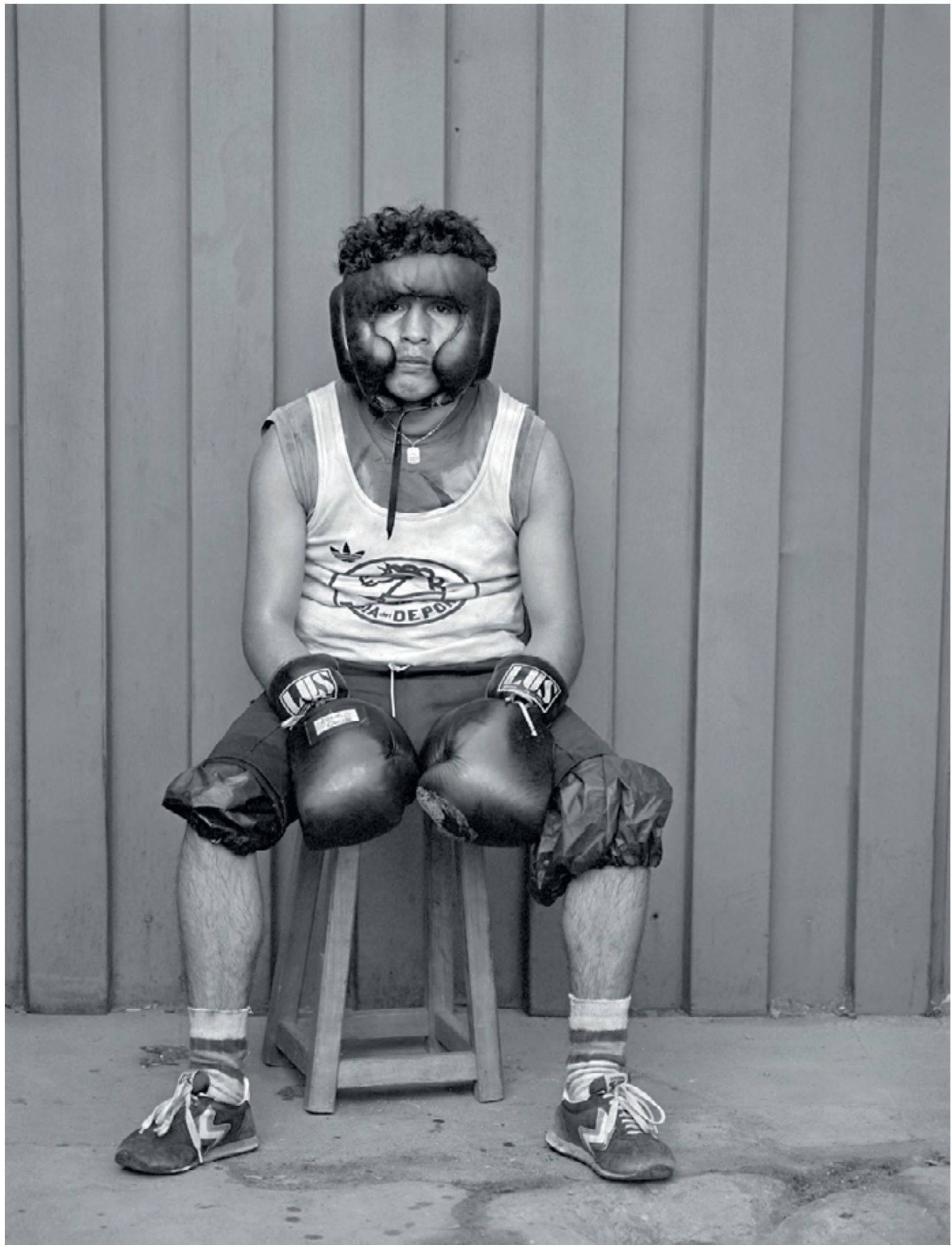




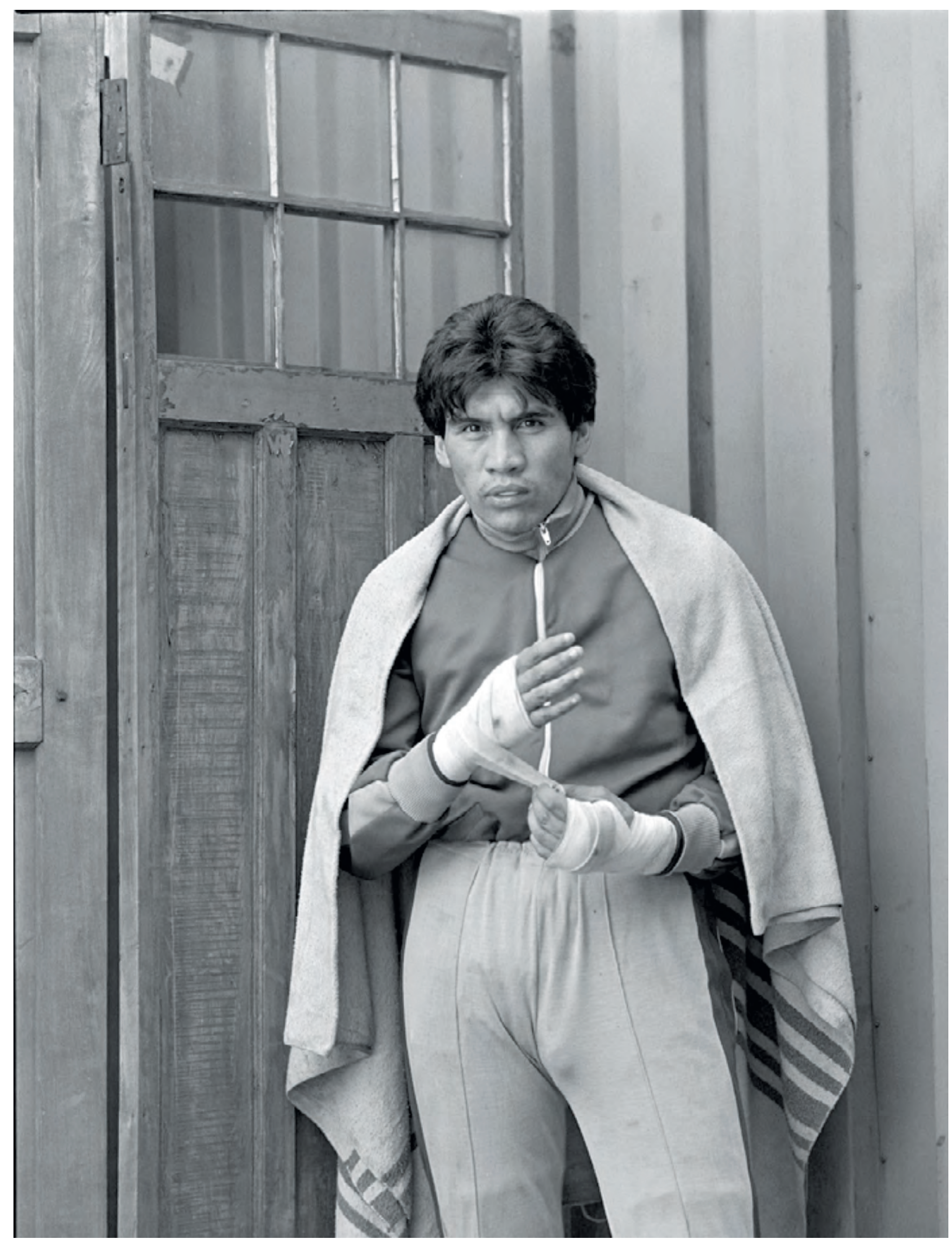

